\title{
THE DAIRY VALUE CHAIN, INCLUSIVE BUSINESS MODEL, AND INCLUSIVENESS IMPROVEMENT OF SOUTHERN BANDUNG DAIRY COOPERATIVE (KPBS) PANGALENGAN
}

\author{
Annisa Ramadanti*), Arief Daryanto*), dan Sukardi**) \\ *) School of Business, Bogor Agricultural University (SB-IPB) \\ Gedung MB-IPB, Jl. Raya Pajajaran, Bogor 16151 \\ **) Department of Agroindustrial Technology, Faculty of Agricultural Technology, Bogor Agricultural University \\ Fateta Building floor 2, IPB Dramaga Campus, Bogor 16002
}

\begin{abstract}
There is an opportunity for smallholder dairy farmers to grow in meeting the increasing demand of milk and milk products in Indonesia. IBM is a suitable method for smallholder improvement. KPBS Pangalengan is one good example of institution which implements IBM. This research aims to analyze KPBS Pangalengan's current dairy value chain, business model, inclusiveness, as well as the possible areas of improvement for its inclusiveness respectively using VCM, BMC, and NBM Principles. Based on the result of this research, there is a tendency of declining fresh milk production in dairy farmer level and a tendency of Milk Processing Industry (MPI) as the chain leaders due to their domination along the chain. Other customer perspective business models have their most weaknesses. The weakest area of KPBS Pangalengan inclusiveness is measurement of outcome area. The four areas of improvement for KPBS Pangalengan inclusiveness include fresh milk production area, IT support area for the downstream side, potential diversifications area (agritourism and milk café concept), and measurement of outcome area.
\end{abstract}

Keywords: inclusiveness, KPBS Pangalengan, Milk Processing Industry, smallholders, value chain

\begin{abstract}
Abstrak: Terdapat peluang bagi peternak skala kecil untuk tumbuh memenuhi permintaan susu dan produk olahan susu yang meningkat di Indonesia. Inclusive Business Model (IBM) merupakan metode yang sesuai untuk pengembangan peternak kecil. KPBS Pangalengan merupakan contoh lembaga yang mengimplementasikan IBM. Penelitian ini bertujuan menganalisis rantai nilai susu, model bisnis, dan inklusivitas KPBS Pangalengan saat ini, serta area pengembangan yang memungkinkan bagi inklusivitas KPBS Pangalengan. Masing-masing analisis menggunakan Value Chain Map (VCM), Business Model Canvas (BMC), dan New Business Model (NBM) Principles. Berdasarkan hasil penelitian ini, terdapat tendensi penurunan produksi susu di tingkat peternak dan tendensi Industri Pengolahan Susu (IPS) sebagai pemimpin rantai akibat dominasinya di sepanjang rantai. Model bisnis perspektif konsumen lainnya memiliki paling banyak kelemahan. Area inklusivitas KPBS Pangalengan yang terlemah adalah area pengukuran hasil. Area pengembangan yang memungkinkan bagi inklusivitas KPBS Pangalengan, yaitu area produksi susu segar, area dukungan teknologi informasi untuk sektor hilir, area diversifikasi potensial (konsep agrowisata dan kafe susu), dan area pengukuran hasil.
\end{abstract}

Kata kunci: rantai nilai, inklusivitas, peternak kecil, KPBS Pangalengan, industri pengolahan susu

\footnotetext{
${ }^{1}$ Corresponding author:

Email: adantypro@gmail.com
} 


\section{INTRODUCTION}

Dairy sector has great potentials in contributing to poverty reduction and rural livelihoods (Samal and Kar, 2016). The potentials of dairy sector in Indonesia come from the demand and supply sides. There has been a growing demand for fresh milk and dairy products in Indonesia where the local businesses are unable to meet the demands (Wright and Darmawan, 2016). Most of the domestic demands (approximately 70\%) are met by imported milk (Nugroho, 2012; Sebayang, 2013). Wright and Darmawan (2016) also state that Indonesian per capita milk consumption (14.3 liters in 2016) is much lower than that of the other ASEAN countries (Malaysia: 50.9 liters; Thailand: 33.7 liters; and the Philippines: 22.1 liters).

The potential of dairy sector from supply side is supported by the fact that the majority of dairy cattle in Indonesia is in the hands of smallholders (Anindyasari et al. 2015). Therefore, there is an opportunity for smallholder dairy farmers to grow in order to meet the growing demand of milk and milk products in Indonesia. Improved income and condition of smallholder dairy farmers may eventually lead to the poverty alleviation.

One suitable method to improve the livelihood of smallholder dairy farmers is by implementing the smallholder-Inclusive Business Model (IBM). According to Kelly et al. (2015), IBM promotes the integration of smallholders into markets with the underlying principle that there are mutual benefits for poor farmers and the business community. Its ultimate goal is to reduce poverty and improve food security. The urgency of considering and conducting IBM in the dairy sector is also driven by the agrifood transformations (Reardon and Timmer, 2014) and dairy transformation (Daryanto, 2015).

Southern Bandung Dairy Cooperative (KPBS) of Pangalengan is one good example of institution which implements smallholder-IBM, specifically in the form of farmer-owned business. KPBS Pangalengan is selected as a great example or case study due to its high rank or large scale and percentage, its location in West Java, its large number of smallholder dairy farmers $(93 \%$ to 94\%), its establishment of automated Milk Collection Point (MCP), and its autonomous units (PT BPR Bandung Kidul and PT MT2 KPBS Pangalengan).
KPBS Pangalengan plays a vital role in linking the smallholder dairy farmers in Pangalengan to the markets. It works in a dairy value chain system from dairy farmers to consumers. It also has its own business model which has the characteristics of smallholder IBM. Therefore, the study about dairy value chain, business model, and inclusiveness of KPBS Pangalengan are expected to be beneficial, especially for smallholder improvement. The study about KPBS Pangalengan dairy value chain is the high level view on the system, and the study about its business model is the close-up one.

In regards to the dairy value chain, there are concerns about the power of Milk Processing Industries (MPI) and modern retail revolution. There is a tendency of oligopsony structure in Indonesian MPI (Farid and Sukesi, 2011). Rapid changes in dynamic modern markets affect the entire value chain with enormous implications for the competitiveness and future viability of small-scale producers (Vermeulen et al. 2008). Therefore, the study about dairy value chain of KPBS Pangalengan using Value Chain Map (VCM) is expected to be helpful for smallholder inclusiveness. The use of Business Model Canvas (BMC), in this study, is mainly intended to understand the overall business model of KPBS Pangalengan.

As there are still many smallholder dairy farmers of KPBS Pangalengan that need to be scaled up, assessing the current state of KPBS Pangalengan inclusiveness using New Business Model (NBM Principles) will also be helpful. The possible areas of improvement for smallholder inclusiveness in KPBS Pangalengan will be supported by the inclusiveness analysis result. Accordingly, this research aims to analyze the current dairy value chain of KPBS Pangalengan, the current business model of KPBS Pangalengan, the inclusiveness of KPBS Pangalengan, and the possible areas of improvement for KPBS Pangalengan inclusiveness based on the results of current dairy value chain, current business model, and inclusiveness analysis.

Dairy in this research refers to milk produced by dairy cows. This research focused only on the case of KPBS Pangalengan, so that the overall situations of milk industry in West Java were not covered. The three analytical tools sequentially used in this research of VCM, BMC, and NBM Principles, are proposed by Lundy et al. (2010). VCM is a tool that helps in studying 
about value chain and divided into three levels, namely, core process mapping, partner network mapping, and external influences mapping. This research mainly covered the core process mapping. BMC is a business modelling tool preformatted with the nine blocks which allows its users to paint pictures of new or existing business models and describe the rationale of how an individual firm creates, captures, and delivers values (Osterwalder and Pigneur, 2010). NBM Principles are signposts for inclusive and durable trading relationships and are designed to be used as critical success factors to guide the process of assessing a business model and selecting areas of change (Lundy et al. 2010).

\section{METHODS}

The data used in this research included the primary and secondary data. The primary data were collected through interviews, questionnaire, and behavioral and non-behavioral observations (physical condition and physical process). The secondary data were obtained through the non-behavioral observation (record observation). The interviews (face to face and telephone) conducted had the characteristics of Individual Depth Interview (IDI) and semi-structured interview. The questionnaire used in this research referred to the NBM Principle scorecard designed by Lundy et al. (2010).
The interviewees and respondents of this research were as follows: 1) the Chairman of KPBS Pangalengan; 2) the Manager of General Administration and Human Resource of KPBS Pangalengan; 3) the Manager of Milk Processing (MT) of KPBS Pangalengan; 4) the GM Manufacturing of PT Ultrajaya; 5) A lecturer from IPB who had conducted his research on Indonesian dairy cooperatives; 6) Thirty dairy farmers of KPBS Pangalengan (members of MCP). Judgment sampling was applied in this research as the interviewees and respondents were chosen on the basis of their expertise.

The five main stages of data processing and analysis of this research are as follows: 1) Dairy value chain analysis (qualitative) using VCM; 2) Current business model analysis (qualitative) using BMC; 3) Inclusiveness analysis (quantitative) using NBM Principles; 4) Possible areas of improvement analysis based on the previous analyses (qualitative); and 5) Managerial implication formulation. Inclusiveness analysis using NBM Principles questionnaire is considered as quantitative analysis as the questionnaire used the interval scale of 0 to 5 . The scale shows the degree of application of each scoring criterion, with 0 means that the criterion "does not apply at all" (lowest degree) and 5 means that the criterion "fully applies" (highest degree). The five main stages are reflected in the conceptual framework of this research as portrayed in Figure 1.

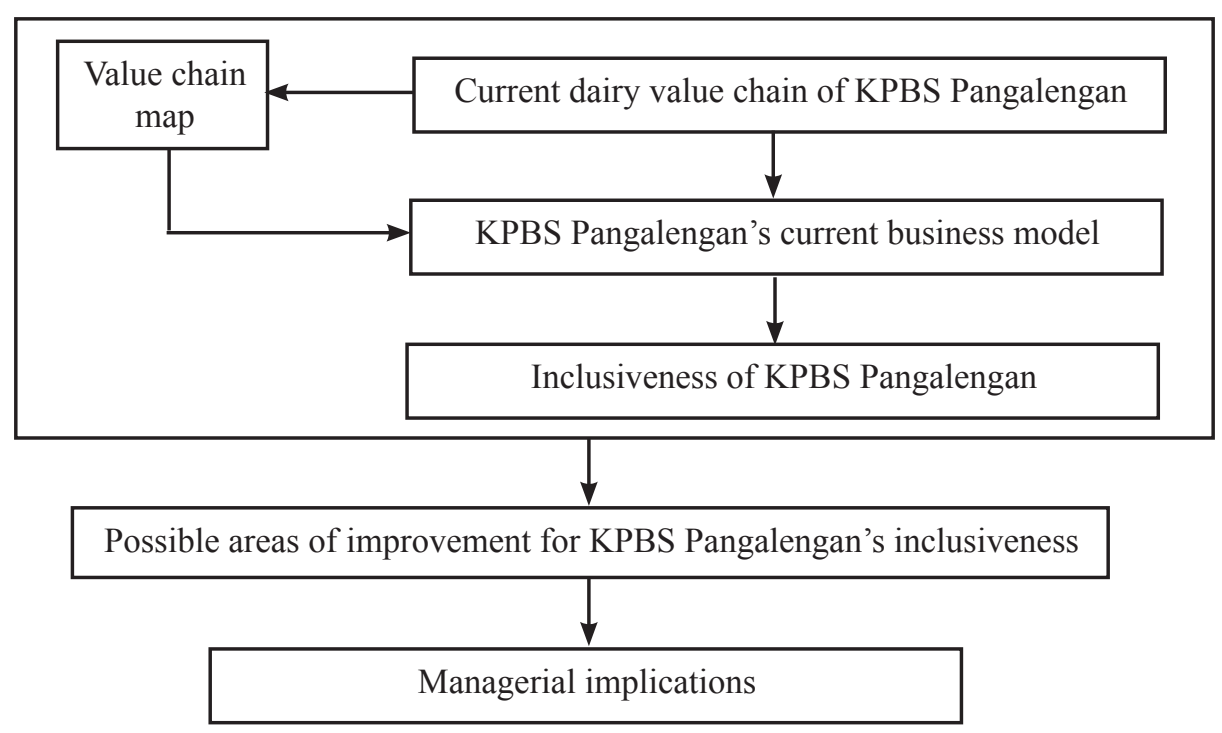

Figure 1. Conceptual framework 


\section{RESULTS}

\section{Current Dairy Value Chain of KPBS Pangalengan}

Dairy VCM of KPBS Pangalengan (the core process) is described in Figure 2. The chain starts from dairy farmers of KPBS Pangalengan as fresh milk producers. Logistics and services needed by the dairy farmers to produce milk peacefully and comfortably are provided by KPBS Pangalengan. The chain continues to these following chain links: 1) Intermediary (TPK/MCP and Milk Treatment 1 or MT1 of KPBS Pangalengan); 2) Fresh milk processors (MPI, Milk Treatment 2 or MT2 of KPBS Pangalengan and home industry); 3) Distributors and exporter; 4) Traders (wholesalers, retailers, hotels, restaurants, and cafes or horeca); and 5) End consumers. MT1 is the milk cooling plant of KPBS Pangalengan, while MT2 is the milk processing plant of KPBS Pangalengan. The key actors of this dairy VCM core process include dairy farmers, KPBS Pangalengan, MPI (FFI and Ultrajaya), and end consumers. It is based on the relatively more important roles of dairy farmer (Alfiah, 2015), KPBS Pangalengan as a dairy cooperative (Priyono and Priyanti, 2015), MPI (Abubakar, 2012), and consumers (Prastiwi and Setiyawan, 2016).

An issue of decreasing fresh milk production exists in the dairy farmer level. It is very critical for the dairy farmers, KPBS Pangalengan, and MPI now and even in the future. MPI has multiple fresh milk suppliers other than KPBS Pangalengan, but MT2 of KPBS Pangalengan main suppliers are the dairy farmers of KPBS Pangalengan. Therefore, it is much more critical for MT2 of KPBS Pangalengan.

The current technological condition of KPBS Pangalengan exists between low and middle technologies. It is due to the establishment of automated MCPs in KPBS. MCPs enable the fresh milk volume, quality, and price to be recorded individually and digitally. The dairy farmers or KPBS Pangalengan can trace the past fresh milk transactions from the digital records. It indicates that the traceability system has been existing in the upstream side of the dairy value chain of KPBS Pangalengan. However, it does not continue to the next actors. It means that the traceability system in the downstream side has not been applied. The traceability in downstream side is highly related to how KPBS Pangalengan connects with the next actors (processors, distributors and/or exporters, traders, and consumers) with the help of information system (technology). It needs to be present along the chain as it promotes food safety (Doğu and Şireli, 2016) which is an ultimate goal of IBM. It promotes food safety as it reflects how the chain actors maintain the food quality and enables consumers to know where their food comes from.

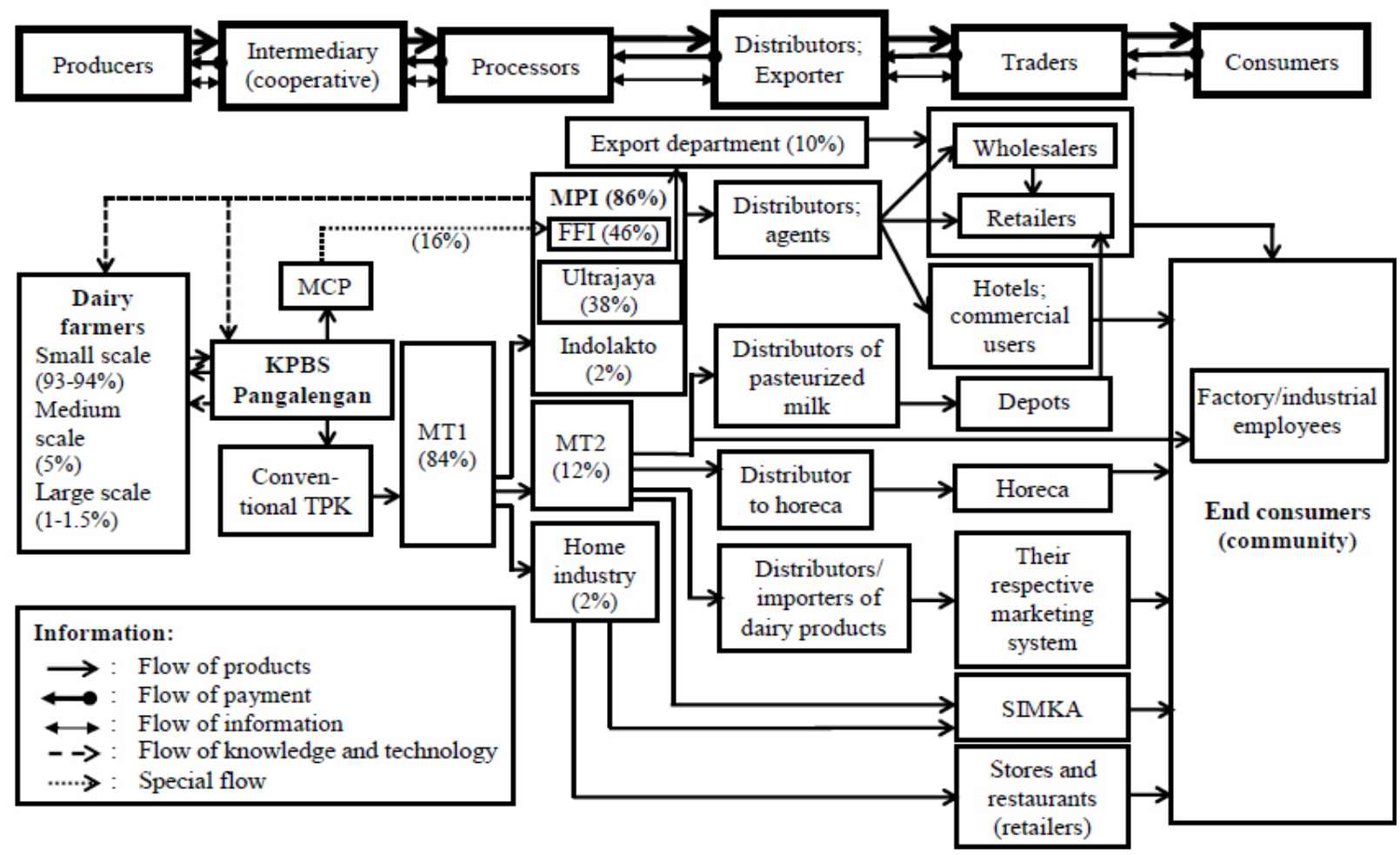

Figure 2. Dairy value chain of KPBS Pangalengan (the core process) 
There is an issue of MPI domination and its relatively stronger position. Although there are four key actors of KPBS Pangalengan dairy value chain, MPI is seen as the most powerful one (chain leaders). Their domination is visible both in the upstream (flow of knowledge and technology; fresh milk price) and downstream (dairy products in domestic market). KPBS Pangalengan and its dairy farmers still highly rely on MPI as their main market. They accept the fresh milk price paid by MPI (price takers) as the price is set according to the commitment between GKSI and MPI (Amaliah and Fahmi, 2007). Their obvious domination is in accordance with the general Indonesian milk market structure that is overpowered by MPI (Priyono and Priyanti, 2015).

An issue of dynamic modern (food) market revolution exists in milk trade sector in the form of hypermarket, supermarket, and minimarket/convenience store revolutions. There is a rapid growth of modern markets in Indonesia, and there is a need to link or integrate small farmers to the modern markets (Reardon et al. 2012). The dairy farmers of KPBS Pangalengan, to date, can only indirectly reach the modern markets through MPI. Milk and dairy products sold in the modern markets are the products of MPI. Meanwhile, products of MT2 of KPBS Pangalengan have not reached the modern markets due to their low competitiveness in capital, brand, and packaging.

\section{Current Business Model of KPBS Pangalengan}

The current business model of KPBS Pangalengan is reflected through three BMCs as it has triple perspective value propositions, namely, dairy farmer perspective, MPI perspective, and other customer perspective. Dairy farmer perspective business model describes how KPBS Pangalengan provides logistics and services for its dairy farmers. MPI perspective business model portrays how MT1 KPBS Pangalengan distributes most of the fresh milk collected from the dairy farmers to MPI and the remaining portion to home industries. Another customer perspective business model depicts how MT2 of KPBS Pangalengan produces dairy products with the brand of KPBS Pangalengan for horeca, manufacturing employees, and communities. The dairy products of KPBS Pangalengan are pasteurized milk, mozzarella cheese, butter, yogurt, semi-finished ice cream, and cream cheese. Each business model has its own strengths and weaknesses. The strengths of each BMC are shown in Table 1, while the weaknesses of each BMC are listed on Table 2.

\section{Inclusiveness of KPBS Pangalengan}

The results of inclusiveness analysis of KPBS Pangalengan based on the six NBM Principles are presented in Table 3 and Figure 3. The results show that measurement of outcome principle has the lowest average score, followed sequentially by chain-wide collaboration principle and effective market linkage principle. Itmeans thatKPBSPangalenganinclusiveness is lacking in those three principles (areas).

Table 1. Strengths of KPBS Pangalengan's BMCs

Dairy farmer perspective business model
Value propositions: The provision of logistics and services by KPBS Pangalengan is acknowledged by the dairy farmers.
Customer relationships: Closest relation with dairy farmers compared to KPBS Pangalengan's other customers
Key resources: Establishment of MCPs
Key partnerships: Establishment of MCPs (with FFI) and colony shed (with Ultrajaya)
MPI perspective business model
Customer relationships: Partnership established with FFI and Ultrajaya
Key resources: MCP
Other customer perspective business model
Revenue streams: Sales of milk products (existing diversification)
Key partnerships: Partnerships with CV Cita Karsa Bersama


Table 2. Possible areas of improvement based on business model analysis

\begin{tabular}{|c|c|}
\hline \multicolumn{2}{|c|}{ Possible areas of improvement } \\
\hline Weaknesses of each BMC & Improvement \\
\hline \multicolumn{2}{|l|}{ Dairy farmer perspective business model } \\
\hline Key Activities: tendency of declining milk production & \multirow{3}{*}{$\begin{array}{l}\text { Functional and process upgrading } \\
\text { Increasing number of MCP, improving colony } \\
\text { shed utilization, applying tie-stall housing } \\
\text { system which allow exercise for cows (Popescu } \\
\text { et al. 2013), etc. }\end{array}$} \\
\hline $\begin{array}{l}\text { Key Relationships: cows (small scale and declining cow population), } \\
\text { challenge of dairy farmer regeneration and land for forages }\end{array}$ & \\
\hline $\begin{array}{l}\text { Key Partnerships: with PTPN VIII, Perhutani, and government } \\
\text { regarding land for forages }\end{array}$ & \\
\hline \multicolumn{2}{|l|}{ Cost Structure: raw material of feeds } \\
\hline \multicolumn{2}{|l|}{$\begin{array}{l}\text { All weaknesses affect the milk production and there is a tendency of } \\
\text { declining milk production }\end{array}$} \\
\hline \multicolumn{2}{|l|}{ MPI perspective business model } \\
\hline Customer Relationships: lack of e-meeting and regular joint meeting & Process, functional, and inter-sectoral upgrading \\
\hline Key Activities: lack of traceability system & $\begin{array}{l}\text { Implementing e-meeting and traceability system } \\
\text { and organizing regular joint meeting }\end{array}$ \\
\hline \multicolumn{2}{|l|}{ Other customer perspective business model } \\
\hline $\begin{array}{l}\text { Value Propositions: unlabeled products, potential diversifications that } \\
\text { have not been conducted (agritourism and milk café) }\end{array}$ & \multirow{5}{*}{$\begin{array}{l}\text { Product, functional, and inter-sectoral upgrading } \\
\text { upgrading } \\
\text { Improving diversification (existing dairy } \\
\text { products, agritourism, and milk café), improving } \\
\text { marketing through website and social media, } \\
\text { implementing CRM and e-meeting, and } \\
\text { adopting regular joint meeting }\end{array}$} \\
\hline Channels and Key Activities: promotion (marketing activity) & \\
\hline $\begin{array}{l}\text { Customer Relationships: closeness with customers and regular joint } \\
\text { meeting }\end{array}$ & \\
\hline $\begin{array}{l}\text { Revenue Streams: potential diversifications that have not been } \\
\text { conducted (agritourism and milk café) }\end{array}$ & \\
\hline Key Partnerships: with BPOM, MUI, and certification agencies & \\
\hline
\end{tabular}

Table 3. Result of inclusiveness analysis of KPBS Pangalengan

\begin{tabular}{lc}
\hline \multicolumn{1}{c}{ NBM principles } & Average score \\
\hline Chain-wide collaboration & 3,71 \\
Effective market linkage & 3,80 \\
Fair and transparent governance & 3,86 \\
Equitable access to services & 4,34 \\
Inclusive innovation & 3,82 \\
Measurement of outcomes & 3,52 \\
\hline
\end{tabular}

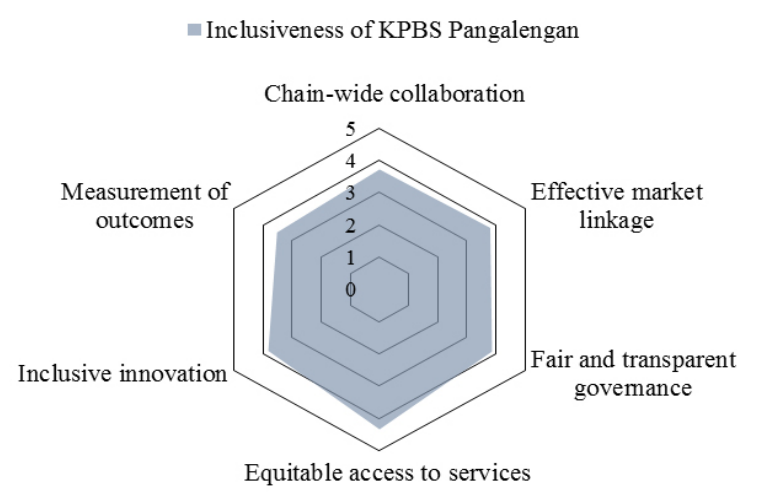

Figure 3. Result of inclusiveness analysis of KPBS Pangalengan
In contrast, the equitable access to service principle holds the highest average score, followed sequentially by fair and transparent governance principle and inclusive innovation principle. It means those areas reflect the strengths of KPBS Pangalengan inclusiveness.

\section{Possible Areas of Improvement for KPBS Pangalengan's Inclusiveness}

The possible areas of improvement for KPBS Pangalengan inclusiveness are derived from the three previous analyses. They are specifically derived from the weaknesses of KPBS Pangalengan dairy value chain, BMCs, and inclusiveness.

Inclusiveness improvement can be sought through product upgrading, process upgrading, functional upgrading, and inter-sectoral upgrading as proposed by Humphrey and Schmitz (2002). Product upgrading means moving into more sophisticated product lines. Process upgrading means transforming inputs into outputs more efficiently by re-organizing the production system or introducing superior technology. Functional upgrading means acquiring new functions (or abandoning existing functions) to increase the 
overall skill content of activities. Lastly, inter-sectoral upgrading means firms of clusters move into new productive activities.

\section{Based on Dairy Value Chain Analysis}

The three weaknesses of KPBS Pangalengan current dairy value chain that reflect the possible areas of improvement for KPBS Pangalengan inclusiveness are shown in Table 4. The improvement can be attempted through product, process, functional, and inter-sectoral upgrading.

\section{Based on Business Model Analysis}

The weaknesses of KPBS Pangalengan BMCs that reflect the possible areas of improvement for KPBS Pangalengan inclusiveness are shown in Table 2. The improvement can be attempted through product, process, functional, and inter-sectoral upgrading.

\section{Based on Inclusiveness Analysis}

The three weaknesses of KPBS Pangalengan inclusiveness that reflect the possible areas of improvement for KPBS Pangalengan inclusiveness are shown in Table 5. The improvement can be attempted through functional and inter-sectoral upgrading.

According to the result of inclusiveness analysis of KPBS Pangalengan, the first possible area of improvement for its inclusiveness is in measurement of the outcome area. It can be improved through the organization of regular meetings among actors and certain partners (especially government) of the dairy chain's key actors (regular joint meetings). It is necessary to discuss important issues of each actor and overall milk sector with the ultimate goal of smallholder improvement. The regular joint meetings can facilitate the improvement of the lacking areas based on the inclusiveness analysis (Table $5)$.

Table 4. Possible area of improvement based on dairy value chain analysis

\begin{tabular}{|c|c|}
\hline \multicolumn{2}{|c|}{ Possible areas of improvement } \\
\hline Weaknesses of KPBS Pangalengan's dairy value chain & Improvement \\
\hline Decreasing milk production in dairy farmer level & $\begin{array}{l}\text { Functional and process upgrading } \\
\text { Increasing number of MCP, improving colony shed utiliza- } \\
\text { tion, applying tie-stall housing system which allow exercise } \\
\text { for cows (Popescu et al. 2013), etc. }\end{array}$ \\
\hline $\begin{array}{l}\text { Lack of IT support (traceability system) for the down- } \\
\text { stream }\end{array}$ & $\begin{array}{l}\text { Process, functional, and inter-sectoral upgrading } \\
\text { Implementing traceability system with MPI }\end{array}$ \\
\hline MPI's domination and modern market revolution & $\begin{array}{l}\text { Product upgrading } \\
\text { Improving diversification (existing dairy products, agritour- } \\
\text { ism, and milk café) }\end{array}$ \\
\hline
\end{tabular}

Table 5. Possible areas of improvement based on inclusiveness analysis

Possible areas of improvement

Weaknesses of KPBS Pangalengan's inclusiveness

(average score)

\section{Measurement of outcomes (2)}

a. Market trends and market position are not jointly reviewed on a regular base (2)

b. The generated information is not shared nad discussed along the chain (2.5)

c. Social and environmental factors have not been included in the evaluation (2.75)

Chain-wide collaboration (2.5)

Commercial goals are not aligned among the actors

Effective market linkage (2.75)

Actors do not rapidly react to changing market conditions
Improvement

Functional and inter-sectoral upgrading

Organizing regular meeting between key actors and certain partners of the dairy chain (regular joint meeting) 
The regular joint meetings have similar essence, importance, and benefits with multi-stakeholder discussions (Bianco et al. 2014), stakeholder dialogues (Alpana, 2014), Multi-Stakeholder Platforms or MSP (Martey et al. 2014), and multi-stakeholder partnerships (Kefasi et al. 2011). MSP can be specially addressed for smallholders (Hounkonnou et al. 2012; Kilelu et al. 2017; and Mulema and Mazur, 2015).

The regular joint meetings can be adopted by KPBS Pangalengan especially to discuss the planning of agritourism concept and milk café concept, and later of its implementation, evaluation, and development. Both concepts, if well-planned and well-executed, have the possibility to involve and improve dairy farmers. Agritourism has the ability to serve benefits for marketing, diversification, quality improvement, and smallholders or small scale farmers (Haugen and Vik, 2008; Brandth and Haugen, 2011; Astuti, 2014; and Çetin, 2015). Meanwhile milk café establishment follows the current growing trend of milk café in several cities, like Cimory Riverside and Momo Milk Barn in Bogor and Kalimilk in Yogyakarta.

\section{Managerial Implication}

The managerial implications generated based on the analysis of possible areas of improvement for KPBS Pangalengan inclusiveness are categorized by the analyses conducted, namely, dairy value chain, business model, and inclusiveness analyses. In terms of dairy value chain, the possible improvements are increasing the number of MCP, improving the colony shed utilization, applying the tie-stall housing system which allows cows to exercise (Popescu et al. 2013), implementing traceability system with MPI, and improving diversification (existing dairy products, agritourism, and milk café). The parties in charge are KPBS Pangalengan, dairy farmers (for colony shed and tie-stall housing), FFI (for MCP), Ultrajaya (for colony shed), KPBS Pangalengan and MPI (for traceability system), and KPBS Pangalengan, MT2 KPBS Pangalengan, and dairy farmers (for agritourism).

In terms of business model, the possible improvements for KPBS Pangalengan inclusiveness are increasing the number of MCP, improving the colony shed utilization, applying the tie-stall housing system which allows cows to exercise (Popescu et al. 2013), implementing e-meetings, traceability system, organizing regular joint meetings, improving diversification (existing dairy products, agritourism, and milk café), improving marketing through websites and social media, implementing CRM and e-meetings, and adopting regular joint meetings. The parties in charge are KPBS Pangalengan, dairy farmers (for colony shed and tiestall housing), FFI (for MCP), Ultrajaya (for colony shed), KPBS Pangalengan and MPI (for e-meetings, traceability system, and regular joint meetings), and KPBS Pangalengan, MT2 KPBS Pangalengan, and dairy farmers (for agritourism).

In terms of inclusiveness, the possible improvements are organizing regular meetings between key actors and certain partners of the dairy chain (regular joint meetings) and organizing regular meetings between key actors and certain partners of KPBS Pangalengan agritourism and milk café concept (regular joint meetings). The party in charge for the regular joint meetings between key actors and certain partners of the dairy chain (regular joint meeting) is the organizer, and the participants are representatives of dairy farmers, each dairy cooperative, MPI, consumers, and certain partners (especially the government). The party in charge for the regular joint meetings between key actors and certain partners of KPBS Pangalengan agritourism and milk café concept (regular joint meetings) would be MT2 of KPBS Pangalengan and the participants would be dairy farmers, KPBS Pangalengan, consumers (after conducted), and certain partners.

\section{CONCLUSIONS AND RECOMMENDATIONS}

\section{Conclusions}

There are four conclusions that can be drawn from this research with regards to the four objectives. The first is that there are several critical issues existing within the dairy value chain of KPBS Pangalengan, namely the declining fresh milk production in dairy farmer level, lack of IT support(traceability system) in the downstream side, MPI domination along the chain, and modern market revolution. Secondly, KPBS Pangalengan does not only handle the fresh milk from dairy farmers to the processors, but also produces dairy products of its own. It is good for KPBS Pangalengan especially when the world milk price declines and the fresh milk standard imposed becomes more complicated. Other customer perspective business model has the greatest weaknesses despite its important role in diminishing the high dependence on MPI. Its weaknesses mainly in the form 
of lack of IT support in Customer Relationships element and other potential diversifications that have not been explored and conducted by KPBS Pangalengan. Thirdly, KPBS Pangalengan inclusiveness in sequence lacks in measurement of outcome, chain-wide collaboration, and effective market linkage. The lack in those areas lies in collaboration of chain actors. The lack is also reflected in the dairy value chain and business model analysis in the form of lack of IT support (traceability system, e-meetings, and CRM) in the downstream side. The last is that there are four three possible areas of improvement for KPBS Pangalengan inclusiveness, namely, fresh milk production area, IT support area for the downstream side, potential diversification area that has not been conducted by KPBS Pangalengan, and measurement of outcomes area. Those areas can be improved through product, process, functional, and inter-sectoral upgrading.

\section{Recommendations}

IT support for the downstream side of the chain as well as within KPBS Pangalengan business model should be made possible. For the dairy value chain of KPBS Pangalengan (downstream side), it is specifically in the form of traceability system. KPBS Pangalengan business model is specifically in the form of e-meetings and CRM to cover broad customer area.

There should be a discussion and decision on the main skilled organizer(s) of the regular joint meetings. The organizer(s) should bear in mind that the ultimate goal of the regular meeting is for smallholder inclusion and improvement. The regular joint meeting requires common understanding of actors and partners involved. Smallholder dairy farmers are the most vulnerable actors of all; therefore, common understanding in improving smallholders' welfare should be cultivated since the beginning.

For the next research, it is highly recommended to study the means to improve fresh milk production, IT support (traceability system, e-meeting, and CRM) for the dairy value chain and business model of KPBS Pangalengan, and potential diversifications that have not been explored and conducted by KPBS Pangalengan (agritourism and milk café concept).

\section{REFERENCES}

Abubakar. 2012. Post-harvest technology innovation and quality management implementation support fresh milk standardization and safety in Indonesia (in Indonesian). Jurnal Standardisasi 14(1):1-12.

Alfiah DT. 2015. The cooperation of Indonesia-New Zealand in dairy cattle farming sector and milk processing industry (in Indonesian). Jurnal Online Mahasiswa (JOM) Fakultas Ilmu Sosial dan Ilmu Politik (FISIP) 2(1):1-12.

Amaliah S, Fahmi I. 2007. Factors influencing Indonesian milk import (in Indonesian). Jurnal Manajemen \& Agribisnis 4(2):91-102.

Anindyasari D, Setiadi A, Ekowati T. 2015. Analysis of income of dairy farmers in Banyumanik Subdistrict, Getasan Subdistrict, and Cepogo Subdistrict (in Indonesian). MEDIAGRO 11(2): 22-33.

Astuti MT. 2014. Agritourism potentials in improving tourism development (in Indonesian). JDP 1(1):51-57.

Bianco M, Cooper J, Fournier M. 2014. Honey bee population decline in Michigan: causes, consequences, and responses to protect the state's agriculture and food system. Michigan Journal of Public Affairs 11 (Spring 2014):4-26.

Brandth B, Haugen MS. 2011. Farm diversification into tourism - implications for social identity? Journal of Rural Studies 27(2011):35-44. https:// doi.org/10.1016/j.jrurstud.2010.09.002.

Çetin I. 2015. Agritourism development model for North Cyprus. Journal of Recreation and Tourism Research 2(2):1-11.

Daryanto A. 2015. Partnering for smallholder inclusive agricultural development models in Indonesia. https://www.adelaide.edu.au/global-food/ research/smallholder-inclusive/Lessons_from_ Dairy_Industry_Development_Models_in Indonesia.pdf. [15 Desember 2015].

Doğu SÖ, Şireli UT. 2016. Determinantion tools of origin in the food traceability. Journal of Food and Health Science 2(3):140-146.

Farid M, Sukesi H. 2011. National fresh milk development for fulfilling national milk requirement (in Indonesia). Buletin Ilmiah Litbang Perdagangan 5(2):196-221.

Haugen MS, Vik J. 2008. Farmers as entrepreneurs: the case of farm-based tourism. International Journal Entrepreneurship and Small Business 
6(3):321-336.https://doi.org/10.1504/ IJESB.2008.019130.

Hounkonnou D, Kossou D, Kuyper TW, Leeuwis C, Nederlof ES, Röling N, Sakyi-Dawson O, Traoré M, van Huis A. 2012. An innovation systems approach to institutional change: smallholder development in West Africa. Agricultural Systems 108(2012):74-83. https://10.1016/j. agsy.2012.01.007.

Humphrey J, Schmitz H. 2002. How does insertion in global value chains affectup grading in industrial clusters?.https://www.ids.ac.uk/ids/global/pdfs/ JHHSRegStudies25jun02.pdf. [8 April 2017].

Kefasi N, Oluwole F, Adewale A, Gbadebo O. 2011. Promoting effective multi-stakeholder partnership for policy development for smallholder farming systems: a case of the Sub Saharan Africa challenge programme. African Journal of Agricultural Research 6(15):34513455 .

Kelly S, Vergara N, Bammann H. 2015. Inclusive Business Models-Guidelines for Improving Linkages between Producer Groups and Buyers of Agricultural Produce. Rome: FAO.

Kilelu C, Klerkx L, Omore A, Baltenweck I, Leeuwis C, Githinji J. 2017. Value chain upgrading and the inclusion of smallholders in market: reflections on contributions of multi-stakeholder process in diary development in Tanzania. The European Journal of Development Research 29(5):11021121. https://10.1057/s41287-016- 0074-z.

Lundy M, Becx G, Zamierowski N, Amrein A, Hurtado JJ, Mosquera EE, Rodriguez F. 2010. Link Methodology: A Participatory Guide to Business Models that Link Smallholders to Markets. Cali: CIAT.

Martey E, Etwire PM, Wiredu AN, Dogbe W. 2014. Factors influencing willingness to participate in multi-stakeholder platform by smallholder farmers in Northern Ghana: implication for research and development. Agricultural and Food Economics 2(11):1-15. https://doi.org/10.1186/ s40100-014-0011-4.

Mulema AA, Mazur RE. 2015. Motivation and participation in multi-stakeholder innovation platforms in the Great Lakes Region of Africa. Community Development Journal 2015:1-17.

Nugroho BA. 2012. The relevance of a rules-based fresh milk price structure policy in East Java: an evidence-based assessment. International Journal of Rural Studies 19(1):1-7.

Osterwalder A, Pigneur Y. 2010. Business Model Generation: A Handbook for Visionaries, Game changers, and Challengers. Hoboken: John Wiley \& Sons, Inc.

Popescu S, Borda C, Diugan EA, Spinu M, Groza IS, Sandru CD. 2013. Dairy cows welfare quality in tie-stall housing system with or without access to exercise. Acta Veterinaria Scandinavica 55(1):43. doi: 10.1186/1751-0147-55-43.

Prastiwi WD, Setiyawan H. 2016. Liquid milk consumption-perception of urban and rural community (in Indonesian). Agromedia 34(1):27-36.

Priyono, Priyanti A. 2015. The strengthening of dairy cooperative institution through the development of national animal husbandry regions approach. WARTAZOA 25(2):85-94. doi: 10.14334/ wartazoa.v25i2.1145.

Reardon T, Timmer CP. 2014. Five inter-linked transformations in the Asian agrifood economy: food security implications. Global Food Security3(2)1:108-117.https://doi.org/10.1016/j. gfs.2014.02.001.

Samal J, Kar AK. 2016. Role of dairy cooperatives in inclusive growth - a revolutionary case of AMUL. Journal for Studies in Management and Planning 2(5):243-257.

Sebayang KDA. 2013. Empowerment the institutional milk cooperation using soft systems methodology. Review of Integrative Business and Economics Research 2(2):449-466.

Vermeulen S, Woodhill J, Proctor F, Delnoye R. 2008. Chain-Wide Learning for Inclusive Agrifood Market Development. London and Wageningen: IIED and CD\&IC.

Wright T, Darmawan B. 2016. Indonesia 2016 dairy and products annual. https://www.fas.usda.gov/ data/indonesia-dairy-and-products-annual-3. [1 Febuari 2017]. 